\title{
Leadership Effects on Employee Perception about CSR in Kurdistan Region of Iraq
}

\author{
Taylan Budur ${ }^{1} \&$ Ahmet Demir ${ }^{2}$ \\ ${ }^{1 \& 2}$ Tshik International University, Sulaimani, Iraq \\ Correspondence: Taylan Budur, Tshik International University, Sulaimani, Iraq. \\ Email: taylan.budur@ishik.edu.iq
}

Received: April 5, 2019

Accepted: May 24, 2019

Online Published: June 1, 2019

doi: 10.23918/ijsses.v5i4p184

\begin{abstract}
Corporate social responsibility has been an emerging issue all around the world after 90's. On the other hand, effect of leadership on feeling and behaving responsibly toward society is incontrovertible. Thus, the question asks which type of leadership would be more effective on the corporate social responsibility practices toward employees of a firm. Hence this research aims to investigate the leadership style influence on the level of CSR practices toward employees. We have collected data from 197 employees of various private corporations in Kurdistan Region of Iraq. Further, we have proposed structural equations modeling to understand the level of impact. The results have shown us that ethical leadership plays much more significant role in CSR practices toward employees than transformational leadership does.
\end{abstract}

Keywords: Corporate Social Responsibility, CSR Practices, CSR to Employees, Leadership, Leadership vs CSR

\section{Introduction}

Organization is a tool that attracts people to create an output for the economy to increase its shareholders and stakeholders' portion as a valued asset (Certo \& Certo, 2012). Shareholder of a company is owner of the shares or real investors of a company (Jones, 2013). And the stakeholders are managers, employees, suppliers, financial and local institutions, governmental agencies, etc., who impact and could be impacted by the activities of an organization in the market (Freeman et al., 2004; Jensen, 2001; McWilliams \& Siegel, 2001). In this respect, businesses exist to survive and increase their portion from the market. Scholars asserting that social activities increase the awareness of a company in society and provide new awareness and attraction for their businesses (Lai et al., 2010). According to governmental regulations, some of the social activities or responsibilities (like; safety in the workplace, healthy production processes, environmental protection, fair wages, and prices, etc.) have a mandatory level to be followed by the companies (Moser \& Martin, 2012; Ramdhony, 2018). Apart from these rules, companies have to find an optimum level to fulfill social activities in the market (Freeman, 1999). On one side they have to increase the profit of the shareholders, on one side they have to satisfy stakeholders and on the other side they can find a profitable point or level to meet social activities for the sake of the public, where they operate (Lee, 2011; Moore, 2001; Waldman et al., 2006).

Further, Leaders role, for accepting new values or principals in the workplace is crucial (Hardjono \& Marrewijk, 2001). For being role model or charismatic side; and their ethical or servant characteristics leaders are more responsible to imply and follow new culture or values in the organizations (Jones, 2013; 
Groves \& LaRocca, 2011). Because of its moral dependability and inner obligations or responsibilities, ethical leaders are relatively tended to be more socially responsible in the organizations (Kanungo \& Mendoca, 1996).

Moreover, in the current literature, there are enough empirical studies about the impacts of transformational and ethical leadership on employee performance, commitment and turnover intentions or the advantages of CSR activities of businesses in the society. But little is known about the differences of CSR responsibilities between the transformational and ethical leadership styles and their effects on the employees. In this context, one of the aims of the current paper is to examine leadership effects on the social responsibility of the organizations and the secondary purpose of the study is to investigate employee's perceptions on the social responsibility in the Sulaymaniyah city of Kurdistan Region of Iraq. To clarify this important research gap in the Sulaymaniyah, 197 employees from various private institutions have been asked to fill a questionnaire in this issue. The data has been processed through structural equations modeling to test the impact of both leadership styles on the CSR practices toward employees. The results show us that ethical leadership had much more impact on the CSR practices toward employees than the transformational leadership style does.

\section{Literature Review}

\subsection{Corporate Social Responsibility (CSR)}

Socially responsible activities of any company represent their awareness about the environment they operate (Trong Tuan, 2012). Scholars noted CSR activities provide following positive advantages for the organizations in the market; financial performance (Ağan et al., 2016; Akin \& Yilmaz, 2016; McGuire et al., 1988), employee engagement, commitment and satisfaction (Gross \& Holland, 2011; Gupta, 2017), enlarged public awareness (Mendibil et al., 2007; Nelson, 2008) customer satisfaction and repurchase intention (Lee \& Shin, 2010; Pérez et al., 2013; Tong \& Wong, 2014) and finally increased organizational effectiveness (Arendt \& Brettel, 2010; Gupta \& Sharma, 2016; Zahra \& LaTour, 1987). Drawing on these outcomes some of the definitions of CSR are as followed;

- McWilliams et al. (2006) define it as "situations where the firm goes beyond compliance and engages in actions that appear to further some social good, beyond the interests of the firm and that which is required by law"

- Guarnieri and Kao (2008) define it as "the continuing commitment by business to behave ethically and contribute to economic development while improving the quality of life of the workforce and their families as well as the local community and society at large."

- Aguinis and Glavas (2012) define it as "social activities of the organizations among organizations, employees and public."

- El Ghoul et al. (2019) define it as "a company's social or environmental behavior that goes beyond the legal or regulatory requirements."

In this context, this paper is going to summarize CSR as companies' awareness and efforts for being environmental-friendly and to support extra activities of the public (people inside and outside of the company) to increase their prosperity and welfare. Additionally, Carroll (1999) noted four steps to follow 
in CSR activities, namely; profit oriented economical responsibilities, law-oriented legal responsibilities, moral and ethics-oriented social activities, socio-cultural extra activities of the companies.

\subsection{Transformational Leadership}

Transformational leaders effect their followers by constructive communication and define a clear vision for everyone in the company (Burns, 1978; Bass, 1990; Groves \& LaRocca, 2011). In addition, they try to inspire subordinates to meet the expectations and act more for the organization (Bass \& Avolio, 1993). Further, four main characteristics of transformational leaders were defined as (Avolio, 1999; Bass, 1990); Idealized behaviors, the charismatic side of the leaders, which involves being role model for the followers. Inspirational motivation comprises their clear expectation about the vision of the company, the future of the followers and their consistent positive behaviors and communications. Intellectual stimulation represents their encouragements to take responsibility to solve problems or to be innovative in the company. And finally, individualized consideration includes leaders' behaviors to understand the needs of employees and providing trainings according to these needs.

In line with their characteristics, Groves \& LaRocca (2011) noted transformational leaders use universal values and emphasize mainly the importance of justice, honesty, equality and human rights for the common vision, follower's attraction and organizational change instead of obedience and punishment.

Regarding the relationship between transformational leadership and employee performance over corporate social responsibility; Groves and LaRocca (2012) found that followers' positive perception about the company's corporate social responsibility partially mediates the relationship between transformational leadership and employees' extra efforts. Du et al. (2013) revealed that transactional leadership has stronger positive effects on CSR and organizational outcomes in comparison to the transformational leadership style. Additionally, Khan et al. (2018) noted that transformational leaders socially responsible efforts in the company positively affects employee's performance.

\subsection{Ethical Leadership}

Riggio et al. (2010) puts forward that ethical leader is someone, who has four fundamental virtues to follow in the organizations (Budur, 2018). These virtues are, according to Plato and Aristotle namely; prudence, fortitude, justice and temperance that have similarity to Al-Ghazali's concept of pleasant ethics, which are wisdom, justice, temperance and courage (Budur, 2018). Further, Trevino et al. (2003); Brown et al. (2005) and Kanungo (2001) noted that ethical leadership is the leader's ethical conducts that comprise two-way communications, personal and interpersonal connections, behaviors and decision procedures that affect others according to ethical concept and rules in the workplace.

Concerning the ethical leadership, CSR and employee performance relationship; aforementioned scholars found a positive correlation between ethical values and employee's commitment and performance in the workplace (Budur, 2018; Riggio et al., 2010). Gao and He (2017) revealed that ethical leadership increase citizenship behaviors of the employees over CSR. Lin and Liu (2017) noted that while turnover intention and burnout negatively affected, CSR and work engagement are positively moderated by ethical leadership. 


\section{Methodology}

The aim of this study is to test the impact of ethical leadership and transformational leadership on the CSR practices of the corporations toward the employees. To do this, we have collected 197 data from various corporations located in Kurdistan Region of Iraq. The collected data has been validated through reliability and validity analysis. Secondly, we have proposed structural equations modeling to test the hypothesis. The questionnaire of this study was adopted from the various studies. The questionnaire includes four dimensions such as Ethical leadership (10 questions), transformational leadership (12 questions), and corporate social responsibility of firm toward NGOs in Kurdistan Region of Iraq (3 questions). Please see Figure 1 for the model of the study.

Respondents, who were employees mainly, have been asked to rate their perceptions for each question. They have rated questions based on the Likert scale that ranged from 1 (strongly disagree) to 5 (strongly agree). The questions were both in Kurdish and in English which were translated by an expert who was a member of academic staff in English language teaching department of Tishk International University (formerly known as Ishik University).

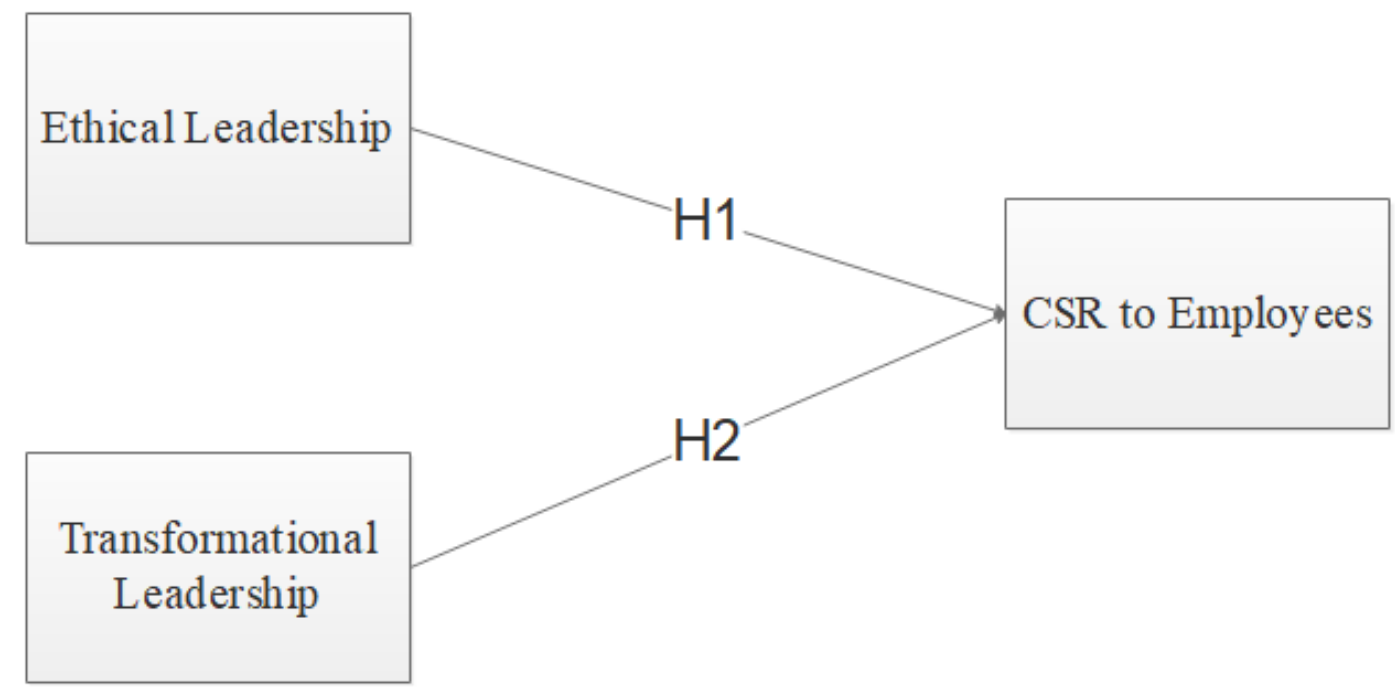

Figure 1: Model of the Study

\section{Data Analysis and Findings}

\subsection{Reliability and validity analysis}

In this section, we have tested the reliability of the questionnaire through Cronbach's Alpha and validity through confirmatory factor analysis (CFA) and discriminant and convergent validity. The results of Cronbach's Alpha have revealed that the value of ethical leadership was 0.945, transformational leadership was 0.961, and CSR to employees was 0.881 . 
Further, in order to test the validity further, confirmatory factor analysis has been proposed. Comparative and absolute model fit values were tracked. It was observed that comparative fit indexes such as CFI (0.95) and Trucker-Lewis' coefficient (TLI, 0.94) were above the threshold values (Olobatuyi, 2006). Furthermore, concerning absolute fit indexes, chi-square (X2/DF, 2.137), root mean square error of approximation (RMSEA, 0.073), good fit index (GFI, 0.85), and adjusted good fit index (AGFI, 0.80) were also at the acceptable levels (Marsh \& Hocevar, 1988; Byrne, 2013).

Table 1: Discriminant and convergent validity

\begin{tabular}{llllll}
\hline & CR & AVE & TL & EL & CSR to Employees \\
\hline TL & 0.963 & 0.686 & 0.928 & & \\
\hline EL & 0.957 & 0.688 & 0.905 & 0.930 & \\
\hline CSR to Employees & 0.884 & 0.717 & 0.667 & 0.714 & 0.847
\end{tabular}

CR: composite reliability, AVE: Average variance extracted, a: Square root of average variance extracted in bold, b: Correlation coefficients not in bold.

Discriminant and convergent validity are another strong determinant. Moreover, convergent validity shows whether each construct is close to each other to become a questionnaire. Besides, Discriminant validity shows whether each construct is away from each other not to have any multicollinearity problem. Discriminant validity is considered to be achieved in case squared root of average variance extracted has value that is above the correlation coefficients of each dimension.

Given in the table above, it has been observed that the squared root of average variance extracted of transformational leadership (TL), ethical leadership (EL), and corporate social responsibility to employees (CSR to Employees) have been respectively 0.928, 0.930, 0.847 which were above the correlation coefficients between each construct. Hence, the discriminant validity has been achieved. However, there have been sufficient relationship between each two variables so that the convergent validity also has been achieved. Finally, the composite reliability (C.R.) and average variance extracted (AVE) had also sufficient values to conclude that the constructs are valid and reliable.

\subsection{Measurement of model analysis}

As the validity and reliability of the questionnaire has been positive, the hypothesis can be tested via structural equations modeling (SEM). In this section, we have tested the impact of transformational and ethical leadership on the corporate social responsibility of a firm toward employees. To do this, maximum likelihood has been selected as model.

Table 2: Model analysis results

\begin{tabular}{lccrrrr}
\hline & & & Estimate & S.E. & C.R. & P \\
\hline CSR Employees & $<---$ & EL & 0.773 & 0.23 & 3.321 & *** \\
\hline CSR Employees & $<---$ & TL & 0.165 & 0.24 & 1.996 & 0.04 \\
\hline
\end{tabular}


Table 2 and Figure 2 illustrate path coefficients with its significance level, the directions and the direct effects between related constructs. Given in the concerning table and figure, it has been observed that ethical leadership (EL) had significant impact on the corporate social responsibility toward employees with $(\beta=0.773, \mathrm{t}=3.321, \mathrm{P}<0.01)$. Further, transformational leadership (TL) had positively and significantly influenced corporate social responsibility practices toward employees $(\beta=0.165, \mathrm{t}=1.996$, $\mathrm{P}<0.05)$. Therefore, $\mathrm{H} 1$ and $\mathrm{H} 1$ have been accepted. Finally, it can be revealed that the leadership styles explained 52 percent of overall variance.

\section{Conclusion}

The aim of this research was to elaborate the impact of ethical leadership and transformational leadership on the corporate social responsibility practices toward employees. To do this, we have collected data from 197 employees of various private corporations. The data has been collected via survey questionnaire. The analysis has been proposed via structural equations modeling.

The results show that ethical leadership, which has 0.773 coefficient value, has much significant impact on the CSR practices toward employees. Besides, it has been observed that the impact of transformational leadership on the CSR practices toward employees has been very little comparing to transformational leadership. The main reason behind this finding might be the ethical leaders care about ethical and social issues of a corporation as well as the organizational goals of the corporations. However, it must also be known that CSR practices toward employees would have very positive impacts on the achievement of organizational goals. The issue can be considered in the next researches in this field.

Although many scholars suggested that the CSR activities provide following positive advantages for the organizations in the market; financial performance (Ağan et al., 2016; Akin \& Yilmaz, 2016; McGuire et al., 1988), employee engagement, commitment and satisfaction (Gross \& Holland, 2011; Gupta, 2017), enlarged public awareness (Mendibil et al., 2007; Nelson, 2008) customer satisfaction and repurchase intention (Lee \& Shin, 2010; Pérez et al., 2013; Tong \& Wong, 2014) and finally increased organizational effectiveness (Arendt \& Brettel, 2010; Gupta \& Sharma, 2016; Zahra \& LaTour, 1987), this study found out that ethical leadership style is better option for these kinds of practices in Kurdistan Region of Iraq.

As every research, this study also contains some limitations. First, the data has been collected only from 197 employees which should be increased in the further researches. Secondly, the study has been conducted in Sulaimani, Kurdistan Region of Iraq and cannot be generalized to all Iraq. In the next studies, the researchers can collect data from all around the country in order to see the whole picture in the region.

\section{References}

Ağan, Y., Kuzey, C., Acar, M. F., \& Açıkgöz, A. (2016). The relationships between corporate social responsibility, environmental supplier development, and firm performance. Journal of Cleaner Production, 112, 1872-1881.

Aguinis, H., \& Glavas, A. (2012). What we know and don't know about corporate social responsibility: A review and research agenda. Journal of Management, 38(4), 932-968.

Akin, A., \& Yilmaz, I. (2016). Drivers of corporate social responsibility disclosures: Evidence from Turkish banking sector. Procedia Economics and Finance, 38, 2-7. 
International Journal of Social Sciences \& Educational Studies ISSN 2520-0968 (Online), ISSN 2409-1294 (Print), June 2019, Vol.5, No.4

Arendt, S., \& Brettel, M. (2010). Understanding the influence of corporate social responsibility on corporate identity, image, and firm performance. Management Decision, 48(10), 1469-1492.

Avolio, B. J. (1999). Full leadership development: Building the vital forces in organizations. Sage.

Bass, B. M. (1990). From transactional to transformational leadership: Learning to share the vision. Organizational Dynamics, 18(3), 19-31.

Bass, B. M., \& Avolio, B. J. (1993). Transformational leadership and organizational culture. Public Administration Quarterly, 112-121.

Brown, M. E., Treviño, L. K., \& Harrison, D. A. (2005). Ethical leadership: A social learning perspective for construct development and testing. Organizational Behavior and Human Decision Processes, 97(2), 117-134.

Budur, T. (2018). The impact of Al-Ghazali's virtues on organizational commitment and performance: A case Study at private education institutions in Kurdistan Region of Iraq. Icabep, Erbil-Iraq, Vol.2, p21.

Burns, J. M., \& Leadership, H. (1978). Row. New York, 280.

Carroll, A. B. (1999). Corporate social responsibility: Evolution of a definitional construct. Business \& Society, 38(3), 268-295.

Certo, S. C., \& Certo, S. T. (2012). Modern management concepts and skills. New Jersey: Prentice Hall

Du, S., Swaen, V., Lindgreen, A., \& Sen, S. (2013). The roles of leadership styles in corporate social responsibility. Journal of Business Ethics, 114(1), 155-169.

El Ghoul, S., Guedhami, O., Nash, R., \& Patel, A. (2019). New evidence on the role of the media in corporate social responsibility. Journal of Business Ethics, 154(4), 1051-1079.

Freeman, R. E. (1999). Divergent stakeholder theory. Academy of Management Review, 24(2), 233-236.

Freeman, R. E., Wicks, A. C., \& Parmar, B. (2004). Stakeholder theory and "the corporate objective revisited". Organization Science, 15(3), 364-369.

Gao, Y., \& He, W. (2017). Corporate social responsibility and employee organizational citizenship behavior: the pivotal roles of ethical leadership and organizational justice. Management Decision, 55(2), 294-309.

Gross, R., \& Holland, B. (2011). Corporate social responsibility and employee engagement: Making the connection. White Paper, pg, 2.

Groves, K. S., \& LaRocca, M. A. (2011). An empirical study of leader ethical values, transformational and transactional leadership, and follower attitudes toward corporate social responsibility. Journal of Business Ethics, 103(4), 511-528.

Groves, K. S., \& LaRocca, M. A. (2012). Does transformational leadership facilitate follower beliefs in corporate social responsibility? A field study of leader personal values and follower outcomes. Journal of Leadership \& Organizational Studies, 19(2), 215-229.

Guarnieri, R.., \& Kao, T. (2008). Leadership and CSR-a perfect match: How top companies for leaders utilize CSR as a competitive advantage. People and Strategy, 31(3), 34.

Gupta, M. (2017). Corporate social responsibility, employee-company identification, and organizational commitment: mediation by employee engagement. Current Psychology, 36(1), 101-109.

Gupta, N., \& Sharma, V. (2016). The relationship between corporate social responsibility and employee engagement and its linkage to organizational performance: A conceptual model. IUP Journal of Organizational Behavior, 15(3), 59.

Hardjono, T. W., \& van Marrewijk, M. (2001). The social dimensions of business excellence. Corporate Environmental Strategy, 8(3), 223-233.

Jensen, M. C. (2001). Value maximization, stakeholder theory, and the corporate objective function. Journal of Applied Corporate Finance, 14(3), 8-21.

Jones, G. R. (2013). Organizational theory, design, and change. Upper Saddle River, NJ: Pearson,

Kanungo, R. N. (2001). Ethical values of transactional and transformational leaders. Canadian Journal of Administrative Sciences/Revue Canadienne des Sciences de l'Administration, 18(4), 257-265

Kanungo, R. N., \& Mendonca, M. (1996). Ethical dimensions of leadership (Vol. 3). Sage. 
Khan, H. U. R., Ali, M., Olya, H. G., Zulqarnain, M., \& Khan, Z. R. (2018). Transformational leadership, corporate social responsibility, organizational innovation, and organizational performance: Symmetrical and asymmetrical analytical approaches. Corporate Social Responsibility and Environmental Management, 25(6), 1270-1283.

Kiliç, M., Kuzey, C., \& Uyar, A. (2015). The impact of ownership and board structure on Corporate Social Responsibility (CSR) reporting in the Turkish banking industry. Corporate Governance, 15(3), 357-374.

Lai, C. S., Chiu, C. J., Yang, C. F., \& Pai, D. C. (2010). The effects of corporate social responsibility on brand performance: The mediating effect of industrial brand equity and corporate reputation. Journal of Business Ethics, 95(3), 457-469.

Lee, K. H., \& Shin, D. (2010). Consumers' responses to CSR activities: The linkage between increased awareness and purchase intention. Public Relations Review, 36(2), 193-195.

Lee, M. D. P. (2011). Configuration of external influences: The combined effects of institutions and stakeholders on corporate social responsibility strategies. Journal of Business Ethics, 102(2), 281-298.

Lin, C. P., \& Liu, M. L. (2017). Examining the effects of corporate social responsibility and ethical leadership on turnover intention. Personnel Review, 46(3), 526-550.

McGuire, J. B., Sundgren, A., \& Schneeweis, T. (1988). Corporate social responsibility and firm financial performance. Academy of Management Journal, 31(4), 854-872.

McWilliams, A., \& Siegel, D. (2001). Corporate social responsibility: A theory of the firm perspective. Academy of Management Review, 26(1), 117-127.

McWilliams, A., Siegel, D. S., \& Wright, P. M. (2006). Corporate social responsibility: Strategic implications. Journal of Management Studies, 43(1), 1-18.

Mendibil, K., Hernandez, J., Espinach, X., Garriga, E., \& Macgregor, S. (2007). How can CSR practices lead to successful innovation in SMEs. Publication from the RESPONSE Project, Strathclyde, 141.

Moore, G. (2001). Corporate social and financial performance: An investigation in the UK supermarket industry. Journal of Business Ethics, 34(3-4), 299-315.

Moser, D. V., \& Martin, P. R. (2012). A broader perspective on corporate social responsibility research in accounting. The Accounting Review, 87(3), 797-806.

Nelson, J. (2008). CSR and public policy. New forms of engagement between business and government. Cambridge, MA: Harvard University Corporate Social Responsibility Initiative-Working Papers.

Pérez, A., del Mar García de los Salmones, M., \& Rodríguez del Bosque, I. (2013). The effect of corporate associations on consumer behaviour. European Journal of Marketing, 47(1/2), 218238.

Ramdhony, D. (2018). The Implications of Mandatory Corporate Social Responsibility-A Literature Review Perspective.

Riggio, R. E., Zhu, W., Reina, C., \& Maroosis, J. A. (2010). Virtue-based measurement of ethical leadership: The Leadership Virtues Questionnaire. Consulting Psychology Journal: Practice and Research, 62(4), 235.

Sulich, A. \& Bogusz, K. (2019). The Sustainable Development Strategies in the Mining Industry. 33rd IBIMA, Granada (Spain)

Tong, C., \& Wong, A. (2014). The influences of corporate social responsibility to customer repurchases intentions, customer word-of-mouth intentions and customer perceived food quality of fast-food restaurants in Hong Kong and the mediating effects of corporate reputation. Journal of Economics, Management and Trade, 1655-1678.

Trevino, L. K., Brown, M., \& Hartman, L. P. (2003). A qualitative investigation of perceived executive ethical leadership: Perceptions from inside and outside the executive suite. Human Relations, 56, 5-37. 
Trong Tuan, L. (2012). Corporate social responsibility, leadership, and brand equity in healthcare service. Social Responsibility Journal, 8(3), 347-362.

Waldman, D. A., Siegel, D. S., \& Javidan, M. (2006). Components of CEO transformational leadership and corporate social responsibility. Journal of Management Studies, 43(8), 1703-1725.

Zahra, S. A., \& LaTour, M. S. (1987). Corporate social responsibility and organizational effectiveness: A multivariate approach. Journal of Business Ethics, 6(6), 459-467. 